\title{
Big Law, Big Data
}

\author{
Special Issue - Comparative Law
}

\author{
Catalina Goanta*
}

\begin{abstract}
It is often claimed in the media and in political and academic debates that more law nurtures more research, which in turn should generate more information. However, the question researchers are left with is the following: What does this mean for comparative law and its methods? This article takes the context of European consumer sales law as an example of the web of rules applicable at both the European and the national levels. In this context the main idea behind this article is that looking at law and research as data to be built upon and used in further analysis can revolutionize the way in which legal research is understood. This is because current research methods in European consumer sales law fall short of systematically analysing the essential weaknesses of the current regulation system. In this contribution, I argue that the volume of regulation in European consumer law is large enough for it to be considered Big Data and analysed in a way that can harness its potential in this respect. I exemplify this claim with a case study consisting in the setting up of a Convergence Index that maps the converging effect of harmonizing policies adopted by the European legislator in the field of consumer sales law. This methodology builds on previous work by Siems on numerical comparative law, as well as on the Consumer Law Compendium database set up by Schulte-Nölke, and fills a gap in consumer literature while showcasing the importance of measurement indices. This contribution emphasizes the need to address the resulting complexity of European consumer sales law by further combining research methods and novel tools to uncover hidden patterns within and relationships between its different components.
\end{abstract}

* Assistant Professor of Private Law, Maastricht Law School, Maastricht University, The Netherlands. 


\section{Introduction}

An online consumer purchase of a phone with the click of several buttons might seem like a victory brought to society by technology and innovation. However, very few of the individuals engaged in mundane transactions such as an online contract are aware of the web of legal rules that apply to their actions. If consumers purchase these products in the European Union, they will have a period of 14 days to return the goods without giving any reason, because the Consumer Rights Directive protects them in this respect. ${ }^{1}$ If the phone is defective, the Consumer Sales Directive kicks in and allows the consumer to ask for the repair or replacement of the phone. ${ }^{2}$ Moreover, the selling company has its own general terms and conditions governing how the consumer ought to use the product in question. If the general terms have clauses that are detrimental to consumers, the Unfair Contract Terms Directive applies. ${ }^{3}$ In addition to this, special national legislation is likely to exist on transposing and complementing matters, not to mention that every jurisdiction has its own default contractual rules, and notwithstanding any additional legal questions that might arise outside of the contractual sphere (e.g. privacy, security, price indication, commercial practices).

The adoption of European norms has led to a high degree of legal and policy convergence. However, national laws remain divergent in many ways, and the assessment of discrepancies is becoming increasingly problematic because of the growing volumes of legislation. So far, comparative law has been the go-to solution for investigating similarities and differences between Member States as a result of harmonization policies. However, the vast complexity of current multilevel governance structures and their policies challenges the usefulness of classical comparative law as a method of investigation for such meta-issues. This article holds that comparative law can be considered Big Data and investigated as such. In other words, more complex and voluminous law and legal interpretations can be either coded into more quantitative observations on the basis of the premises of numerical comparative law, or, alternatively, they can be analysed with the help of new research technologies.

The illustration above shows how law reflects society. The more complex society is, the more complicated law becomes. This can be seen in the increasing volume of law produced to keep up with the needs of contemporary realities. The process of juridification, in other words, the growth of law and regulation as well as the creation of legal structures to facilitate new rules, is thus not unheard of. ${ }^{4}$ Many factors contribute to the increasing volumes of legislation, but two stand out in particular: multi-tier governance and socio-economic developments. The

1 Directive 2011/83/EU on consumer rights, OJ L 304/64 of 22 November 2011.

2 Directive 1999/44/EC on consumer sales and associated guarantees, OJ L 171 of 7 July 1999.

3 Directive 1993/13/EEC on unfair terms in consumer contracts, OJ L 25/99 of 21 April 1993.

4 'Juridification' is a concept with many facets, presently referred to as the proliferation of law. See, for instance, Teubner 1987; 1998. See also Blichner \& Molander 2005; Chevalier 2016; 2008, pp. 36-54; Levi-Faur 2005, pp. 451-462; Magnussen \& Banasiak 2013, pp. 325-339. 
first factor mirrors how law-making bodies can exist in the contemporary legal order at the municipal, national, federal, regional and international levels, all of which can issue legal rules. The second factor addresses socio-economic changes driven by additional influencing forces such as technology, which challenge existing legal frameworks and increase the need to create new, more fitting regulatory responses.

The legislative measures taken by the European Union echo these factors. While playing its own part in the regulatory setting, the European Commission has been trying to fine-tune the interventions of the European legislator. In the 2010 Communication on Smart Regulation, the Commission acknowledged that the European body of legislation must be managed more systematically, and that must be done by evaluating the functioning and effectiveness of existing legislation. ${ }^{5}$ These policies must be considered in light of other interests of the Commission as well. In the case of consumer law there currently is a visible trend of competence creep as the European Commission keeps identifying barriers that hinder cross-border trade and that can allegedly be removed through further regulation (Bull et al. 2015). Consequently, at the national level, such rules need to be accommodated through transposing legislation. To illustrate this point, reference can be made to the two most recent proposals of the European Commission on goods and digital content. ${ }^{6}$ Meant to raise the standard of consumer protection in online transactions, these two proposals add to the already complex piecemeal regulatory framework governing this field.

Furthermore, the Commission aims to provide an evidence-based background for legislative proposals regarding consumer protection, in the form of fitness checks or regulatory impact assessments. ${ }^{7}$ While such fitness checks might include Eurostat observations, or even discussions of stakeholder consultation groups, they also include comparative legal analyses of existing legislation from different countries. The evidence collected in these attempts takes the form of country reports with a high level of detail, which makes the application of classical comparative methodologies to $28 \mathrm{Member}$ States insufficient to determine the performance of existing laws and the need for more regulation. Classical comparative law is doctrinal in nature (Siems 2014, p. 13), and so is the legal analysis expected in comparative reports delivered for the European Commission. ${ }^{8}$

$5 \operatorname{COM}(2010) 543$ final, p. 3.

6 COM/2015/634 final; COM/2015/635 final.

7 In the case of the recent proposals, the Commission drafted an Impact Assessment that included data from a Fitness Check conducted in the framework of the Regulatory Fitness and Performance Programme (REFIT), European Commission, Report of the Fitness Check on Directive 2005/29/EC, Directive 93/13/EEC, Directive 98/6/EC, Directive 1999/44/EC, Directive 2009/22/EC and Directive 2006/114/EC, SWD(2017) 209 final. See also European Commission, Impact Assessment Accompanying the Document Proposals for Directives of the European Parliament and of the Council (1) on certain aspects concerning contracts for the supply of digital content and (2) on certain aspects concerning contracts for the online and other distance sales of goods, SWD(2015) 274 final.

8 Comparative reports often employ the questionnaire method and may be complemented by empirical methods such as using surveys on a small number of relevant stakeholders. 
Legal scholarship has been delivering prompt answers to a plethora of issues arising from the transposition of European legislation, but in doing so has equally contributed to the development of increasing volumes of literature, most of which embrace doctrinal approaches. In other words, more law has attracted even more interpretations.

While statistics are not easy to retrieve in order to map the increase in legal literature generated in a given jurisdiction, some proxies can be used to indeed confirm either that there is more research being funded today in the world than several decades ago or that certain topics have gained an enhanced academic attraction. For instance, according to Eurostat, gross domestic expenditure on R\&D (GERD) has been generally on the rise in the EU, Japan, China and the US as of 2005. ${ }^{9}$ Similarly, to follow up on the consumer protection example, the academic popularity of literature in this field of law can be checked with tools such as Google Ngram, which charts the frequencies of a given sequence of text in all Google Books data (see Figure 1).

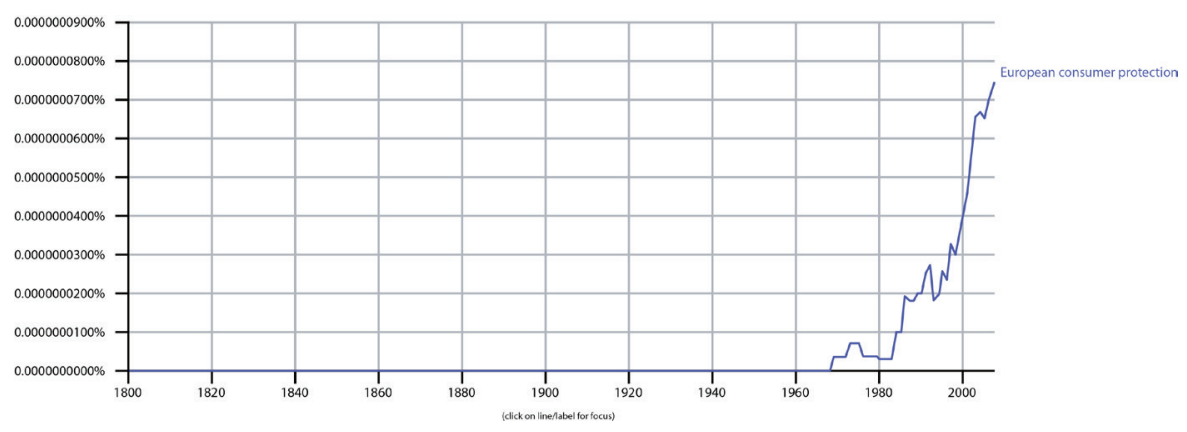

Figure 1 Google NGram Viewer for search on 'European consumer protection'

But what exactly do these trends mean for comparative law and its methods? All in all, there is more law and more research on law in the world today than at any other given point in history, and with the help of technology, this trend is persisting. Laws from different countries can be considered as data that needs to be analysed and processed according to a certain methodology. Therefore, looking at laws and research as data to be built upon and used in further analysis can

9 Gross domestic expenditure on R\&D (GERD) includes expenditure on research and development by business enterprises, higher education institutions as well as government and private non-profit organizations, see Eurostat. http://ec.europa.eu/eurostat/statistics-explained/ index.php/R_\%26_D_expenditure. Last visited on 24 July 2017. 
revolutionize the way in which legal research is understood. Moreover, visualizing the underlying data can lead to observing new patterns and drawing new conclusions with respect to legal developments, the potential of which is already explored by innovative methods such as the use of network analysis software for legal research, as I will discuss later on. In other words, traditional comparative legal research is also affected by the growing amount of laws and legal interpretations, be it in the practice of law or in legal academia. This raises questions about the role of comparative law in the information society.

In this contribution, I argue that the volume of regulation in European consumer law is large enough for it to be considered Big Data and analysed in a way that can harness its potential as Big Data. Taken in a more technical meaning, Big Data is simply a mass of data that is not structured like traditional datasets and needs more real-time analysis (Chen et al. 2014, pp. 171-209). Such analysis can include coding the law or legal observations. The benefits of investigating such data masses lie in the fact that new patterns can be drawn from the information and new lessons can be learned in terms of management and visualization. Perceiving the law as a source of information that can be systematically collected for further analysis can change the way in which the success or the failure of a certain policy is perceived and visualized.

This article proceeds as follows. As it takes European consumer sales law as an example for the overarching discussion, the first part focuses on the features of this field, serving as a background for this analysis. This part also discusses the methodological particularities in existing European consumer sales law research. The second part of this contribution is centred around a case study further building onto European consumer sales law, proposing a novel methodology for measuring the converging effect of European harmonization policies in this area: the Convergence Index. This methodology is rooted in previous work by Siems on numerical comparative law, considered to be a translation of law as such into numbers (Siems 2009; see also Siems 2005, p. 521), as well as on the Consumer Law Compendium database set up by Schulte-Nölke (Schulte-Nölke et al. 2009), and it focuses on filling a gap in consumer literature while showcasing the importance of measurement indices. The third part tackles the need to create alternative methodologies by using the increasing volume of law and research as data while also incorporating the usefulness of doctrinal research, and discusses the relevance of comparative law in this context. Lastly, before presenting its conclusions, this article puts forth several practical solutions in support of alternative comparative methodologies. 


\section{Researching European Consumer Contract Law}

\subsection{A Brief Incursion into the History of European Consumer Contract Law}

The European legislator started looking into consumer law as of the $1980 \mathrm{~s},{ }^{10}$ when European private law instruments on consumer protection were first adopted to enhance cross-border activity by empowering consumers in business-to-consumer ('B2C') transactions, which would in turn lead to a better functioning internal market with more internal trade. ${ }^{11}$ These two features - consumer protection as a normative goal and the view that such a goal contributes to further economic integration - are the main driving forces behind any measure taken on European consumer contract law. ${ }^{12}$ Aiming to get rid of regulatory barriers and bring transaction costs down for companies wanting to operate throughout Europe, the Commission has been making the case for harmonization as a policy leading to legal convergence.

More regulation dealing with economic integration followed. ${ }^{13}$ Given the different national preferences and policies of the Member States, political consensus has been a burden on the Commission's aim to bring about more harmonization. So far, this has shadowed any ideological development destined to strengthen the notion of European identity, such as a potential European Civil Code (Lookofsky 2000, p. 111). ${ }^{14}$ Lacking a centralized codification that it could belong to, consumer protection in Europe has been evolving in 'piecemeal' form, as it is often referred to (Twigg-Flesner 2012, pp. 1369-1378. This entails that consumer

10 For example, Directive 85/374/EEC or Council Directive 85/577/EEC of 20 December 1985 to protect the consumer in respect of contracts negotiated away from business premises, OJ L372 of 31 December 1985. See Cafaggi 2008, pp. 289-352; Goode 2003.

11 European Commission 1985. 'White Paper on Completing the Internal Market', COM(85) 310.

12 This normative dimension of European consumer protection is a very particular characteristic of the European Union, seen from the perspective of other legal systems as a paternalistic approach to consumer regulation, aimed at reducing the asymmetric bargaining power distribution in B2C transactions by often placing businesses under heavy regulatory compliance obligations. For a critique of the European harmonization approaches, see Bar-Gill \& Ben-Shahar 2013, pp. 109-126. This rationale is also used in more recent proposals of the European Commission, see SWD(2015) 274 final, p. 5.

13 See, for instance, Directive 97/7/EC of the European Parliament and of the Council of 20 May 1997 on the protection of consumers in respect of distance contracts, OJ L144 of 4 June 1997; Directive 1999/93/EC of the European Parliament and of the Council of 13 December 1999 on a Community framework for electronic signatures, OJ L013 of 19 January 2000; Directive 2000/31/EC of the European Parliament and the Council of 8 June 2000 on certain legal aspects of information society services, in particular, electronic commerce, OJ L178 of 17 July 2000; Directive 2008/48/EC on credit agreements for consumers, OJ L133/66 of 22 May 2008; Directive 2011/83/EU of the European Parliament and of the Council of 25 October 2011 on consumer rights, amending Council Directive 93/13/EEC and Directive 1999/44/EC of the European Parliament and of the Council and repealing Council Directive 85/577/EEC and Directive 97/7/EC of the European Parliament and of the Council, OJ L304/64 of 22 November 2011.

14 Further attempts at overarching regulation were made in support of the optional instrument Common European Sales Law, but this proposal was finally withdrawn by the Commission in 2015 after heavy criticism. See also Loos 2007, p. 517; Micklitz 2002, pp. 583-598; Staudenmayer 2005, pp. 95-104. 
protection directives focus either on specific transactions (e.g. distance selling, doorstep selling, consumer rights, etc.) or on specific issues that might arise in consumer transactions (e.g. unfair contract terms, remedies for nonconformity). Another dimension of the harmonization discussion in European consumer contract law is that of the harmonization standard itself. Member States have traditionally enjoyed the discretion of setting their own standards for consumer legislation, some opting for stronger protection, while others for lesser. Moreover, new Member States such as Romania, Bulgaria and Croatia pose even more complex issues, as markets and general consumer empowerment are specific to the socio-economic development of a country. As a policy technique pursued by the European legislator, harmonization has had its own shifts.

The earlier directives used standardization as a means of legal convergence (see for instance van Leeuwen 2017, p. 36). While this approach might work for fields or transactions that require technical specifications, standardization was not something suitable for more sophisticated legal issues. For this reason, it soon turned into a minimum harmonization standard, in other words, the lowest common denominator. This would still allow Member States to offer more protection in their own national regimes. More recent times have seen yet another shift, this time to maximum harmonization, expected to align all Member States to the same standard that would then be applicable throughout the entire European Union. ${ }^{15}$

\subsection{The Features of Research on European Consumer Sales Law}

Researching European consumer contract law or, more broadly, European private law in general, reveals different interlinked issues that reflect the specific complexity of this field and that deal with: (i) the need for regulation (should certain issues be regulated, and if so how and at what level of governance, etc.); (ii) regulation itself (if a new directive of national law is passed, what is the scope of such regulation, how is it interpreted by relevant courts, what is the perceived quality of its content, etc.); and (iii) the assessment of regulation (what is the impact of the regulation, how does it affect its stakeholders, does it meet its purpose, etc.). Many of the questions falling under the aforementioned issues can be visited from the perspective of classical legal research methods (van Hoecke 2015, p. 6). For instance, before a directive is adopted, in recent times the Commission has been performing fitness checks aimed at understanding the vulnerabilities of the existing system, as well as at providing the European legislator with more arguments on which to base future legislative reform. Fitness checks are usually performed by private research consultancies working together with academic communities and are awarded as research projects under public procurement

15 The Court of Justice of the European Union (CJEU) has greatly contributed to the interpretation of harmonization standards in different aspects of consumer protection. The CJEU has been playing a particularly important role in interpreting directives the application of which has led to a lot of confusion among national judges, such as the Unfair Contract Terms Directive. See Sørensen 2016, pp. 791-822; see also Micklitz \& Reich 2014, pp. 771-808. 
grants. Depending on the scope of the fitness check, such measures most likely entail some form of economic analysis complemented by an overview of rules in different Member States, reported on the basis of the questionnaire method.

After a proposal is drafted and starts being circulated between the Commission, Council and Parliament, it gives rise to a large volume of academic commentary and reports from civic society and/or industry. Academic literature then addresses whatever criticism is necessary from many different perspectives, including the doctrinal approach (Smits 2017; Vranken 2012, p. 42), the 'law and...' approach ${ }^{16}$ or through various comparisons with other legal instruments (see, for instance, van Zelst 2008). After the directive is adopted, national legislators must accommodate it through transposition measures, which in turn lead to further commentaries, this time also from judicial bodies tasked with the interpretation of such rules. After all Member States transpose the European rules into their national legal systems, the Commission usually performs implementation checks, very similar to fitness checks in the way they are awarded as well as designed.

One of the widest-ranging such studies dealing with consumer contract law is the Consumer Law Compendium, which analyses the transposition of eight different consumer directives such as on sales, unfair terms, distance, doorstep selling as well as package travel and timeshare into the national laws of all Member States. ${ }^{17}$ Once more, a questionnaire template is used to tackle the same issues for all Member States and directives under scrutiny. One of the added benefits of this study used to be the online database providing an article-by-article overview of the transposition, showcasing exactly where in their national legislation Member States transposed the relevant European rules, and sometimes linking such information to relevant case law; however, this resource is no longer available. ${ }^{18}$ One of the vulnerabilities identified in the assessment of regulation on European consumer contract law is that such assessment currently does not tackle the most stringent question prompted by the intense harmonizing policies: does more harmonization (and thus more legal convergence) lead to a better functioning internal market? ${ }^{19}$

16 For instance, law and economics, see Gómez-Pomar \& Ganuza 2011, pp. 27-56; Gómez \& GiliSaldaña, 2014, pp. 331-364.

17 At the time when this study was conducted, Romania, Bulgaria and Croatia were not yet Member States. Romania and Bulgaria were later included in the study.

18 The database used to be hosted at www.eu-consumer-law.org, but is no longer available, although it is still featured on some of the pages of the Commission's website. The Commission tried to operate a similar database for the Unfair Commercial Practices Directive: https://goo. gl/eCQP4T; however, it has not been updated since October 2015.

19 This vulnerability was raised, among others, by law and economics scholars at a conference focusing on the Common European Sales Law at the University of Chicago in 2012; see, for instance, Richard Epstein's comments: 'But the Brussels Commissioners do not explain why or how this one single strategy works better than a decentralized approach that consciously puts multiple Member States in direct competition with each other', in Epstein 2012, p. 6. 
The specific details of the economic effects of legal convergence are for now not fully understood, given the monumentally complex concerns posed by this question. Such concerns might even entail an acknowledgment that science (including legal science) might never be sophisticated enough to identify a clear causal link between legal convergence and a healthy internal market. However, this concept raises two points: first, that if such an effect cannot be established, then the Commission should not use it as an argument to justify its intrusion into this policy field; and, second, that even if a clear causal link might be out of reach, this realization does not negate the need for the scientific community to understand as much as it possibly can from the European regulation environment as it is currently shaped.

To summarize, current methods used to understand European consumer contract law fall short of addressing the essential weaknesses of the current regulation system, because the classical methods of comparing legal provisions and understanding similarities and differences are simply not suitable for the vast amount of legal observations that need to be scrutinized. Moreover, the design of comparative law as a research method leads to a limited aggregation of results, which means further research can build on such outcomes only in an incremental manner. This contribution therefore emphasized the need to address the resulting complexity of European consumer contract law by further combining research methods and novel tools to uncover hidden patterns within and relationships between its different components. As explored in the next section, this is exactly what the Convergence Index aims to do.

\section{Case Study: The Convergence Index}

As we have seen, European consumer contract law is a very regulation-intense field of European law that receives a lot of attention within and beyond the policy cycle. However, all the information produced to analyse this field is fragmented and unaggregated, owing to the research methods traditionally used in its exploration. Regardless of how much quality can be derived from doctrinal analyses on the harmonization of consumer law, one perspective of this discussion remains under-represented in the literature: the need to empirically measure how much legal convergence has been achieved through the policies of the European legislator.

Inspired by the OECD Composite Indicators Handbook (OECD 2008), Siems' 'numerical comparative law' approach (Siems 2005, pp. 521-540; Siems 2014, pp. 146-187) and the 'Courts' study by Djankov et al. (2002), the Convergence Index is an aggregate metric aimed at measuring the level of legal convergence occurring as a result of the transposition of European directives into national legal systems. The Convergence Index aims to add value to existing research in four different ways by: (i) triggering a discussion regarding what harmonization policies have achieved so far; (ii) exploring what factors are important for convergence and their performance; (iii) offering proof that maximum harmonization does not necessarily lead to much more convergence than minimum 
harmonization; and (iv) laying the foundation for additional research to potentially test the hypothesis that more harmonization leads to a better functioning internal market. ${ }^{20}$

The Index includes thirteen separate indicators, seven of which reflect the European governance level, while the remaining six mirror national regulation (see Figure 2). The indicators have been chosen on the basis of a thorough comparative study that looked at the selected directives (Doorstep Selling, Unfair Contract Terms, Distance Selling, Consumer Sales and Unfair Commercial Practices) and selected Member States (Belgium, France, Germany, Ireland, the Netherlands, Romania, the United Kingdom) to understand what influences the convergence of legal systems in the field of European consumer sales law. The most important consideration to keep in mind is that the Index only reflects the transposition process within the regulatory framework and does not extend to implementation, namely the application of European rules by national courts or practitioners. The reason why this was excluded from the study is mostly based on the fact that sources of information on this matter are inconsistent in the jurisdictions selected for this research: while the Netherlands, Germany and France may have consolidated databases available at the national level for case law inquiries, Romania does not, as the few privately held databases do not publish case law consistently and systematically (Goanta 2016, p. 168).

\section{CONVERGENCE INDEX}

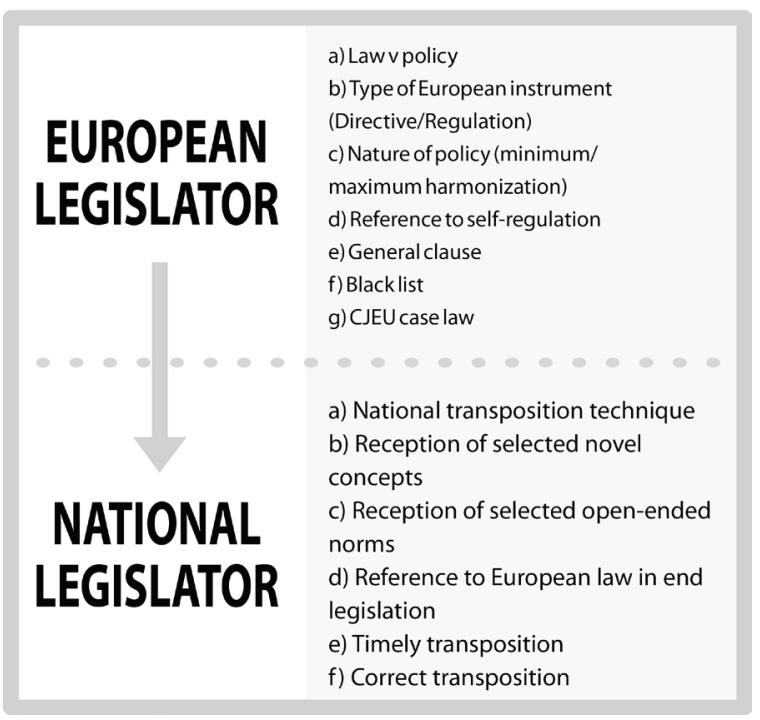

\section{Figure 2 Convergence Index variables}


The idea behind the Convergence Index is to treat law as data that can be coded. This is most certainly not a novel approach (see, for instance, Marotta-Wurgler 2007, pp. 677-713), but this tool reflects the first time such an approach has been applied to substantive European consumer contract law and used in a metric format. The European Commission entertains benchmarking efforts in tools such as the Single Market Scoreboard, but the variables currently included in the Scoreboard exclusively reflect administrative obligations, and do not pay any particular attention to substantive legal issues or detailed aspects of the transposition process. For this purpose, the coding process for each of the factors in Figure 2 started out with an assumption relating to the converging effect of a set of factors characteristic of the process of legal harmonization. For instance, when dealing with the nature of policy, it is assumed that maximum harmonization leads to more convergence than minimum harmonization; or that using open-ended (general) clauses and tests in the body of a legislative instrument can lead to diverging applications, and thus the converging effect of such a practice will not be high. These assumptions allow for the setting of a protocol on the basis of which the coding can be done. This way, binary values can be given to observations arising from the factors. To use the example already discussed, if a general clause is present in a directive it can be noted with '0', whereas if the clause is absent this can be noted with a '1'. ${ }^{21}$ As mentioned above, this approach has been used in the past to code standard terms and conditions in the software industry (Marotta-Wurgler 2007).

But what exactly can the Convergence Index do for the clarity of European consumer contract law? In a nutshell, it can visualize the performance of selected Member States on certain European directives. The original study was based on five directives and seven Member States, bringing together a total of 35 observations. The more observations included in a transposition study (whether instruments or countries), the more sense it makes to use a visualizing tool such as the Convergence Index. Going back to the Consumer Law Compendium, it covered 8 directives and 27 Member States, totalling 216 observations. Not even the best executive summary of such a report can crunch the similarities and differences together in a manner that can be easily visualized and understood as a whole. Coding legislation and aggregating the subsequent results allows for the use of flexible and interchanging perspectives from which the data can be analysed. For example, the indices in the Convergence Index can be explored at each of the two levels of governance they belong to (see Figures 3 and 4). These graphs indicate the aggregated levels of the two different dimensions of the Convergence Index.

21 For a full overview of the assumptions and the coding of all factors included in the Covergence Index, see Goanta, 2016, pp. 168-177. 


\section{Convergence Index (EU)}

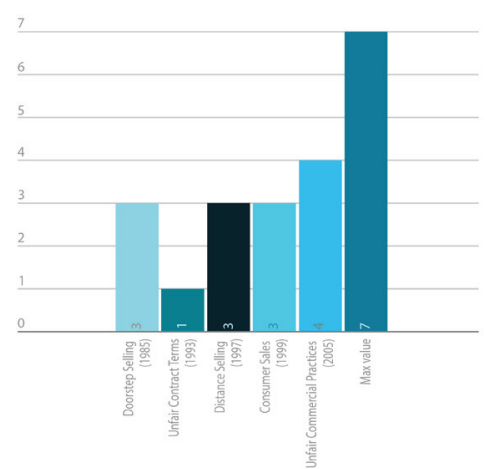

\section{Unfair Contract Terms Directive}

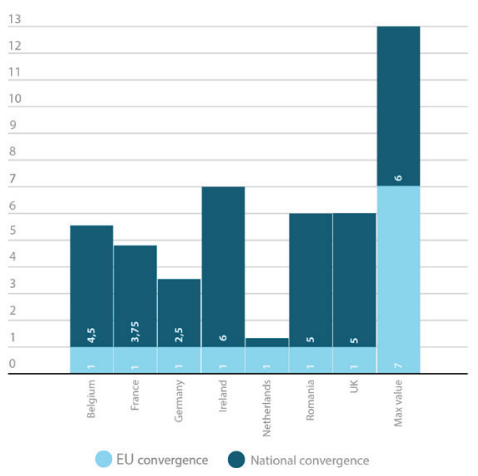

Figure 3 (left) and 4 (right) EU convergence; EU convergence and national convergence for the UCTD

It can be observed that some directives (Unfair Contract Terms) score lower than others (Unfair Commercial Practices), which can be of help in assessing legislative performance employing other methods than doctrinal comparisons. Similarly, while the consumer literature has been qualitatively looking at transposition processes, a clear picture on how Member States rank on the same indicators as those established by the Convergence Index was lacking, but can now be visualized with the graphs resulting from the use of the Index.

Moreover, even tools other than simple graph generators can be used to further explore the data. For any data that makes use of time series, tools such as the Google Motion Graph can be deployed to see the time evolution of the observations. For the Convergence Index, the time stamps in Figure 5 reflect the time of the adoption of the five specific directives in the original study (Doorstep Selling, Unfair Terms, Distance Selling, Consumer Sales and Unfair Commercial Practices) and showcase legislative trends with respect to the transposition of European consumer sales law. 


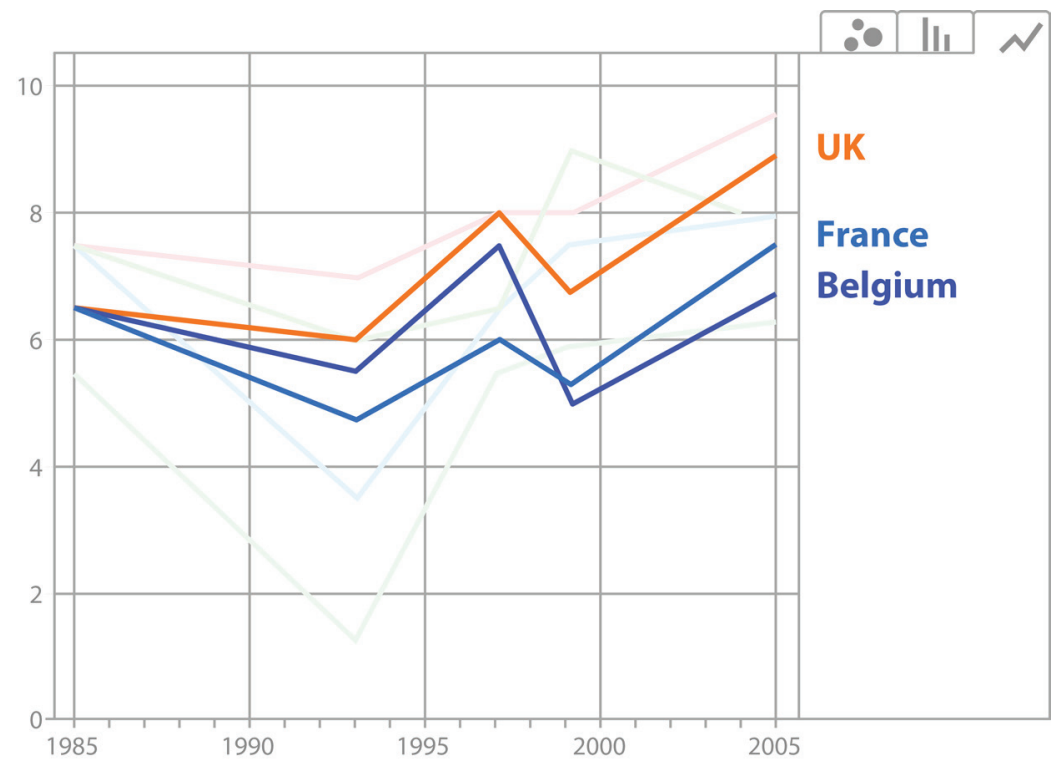

Figure 5 Google Motion Graph for five directives and seven Member States. (The most well-known scientific application using the Google Motion Graph is Hans Rosling's Gapminder tool, exploring United Nations development statistics. http://www.gapminder.org.)

While the conclusions based on such an aggregate index further depend on the use of the visualization tools and the very manner in which the Index is designed, one universal point can be made about the usefulness of the Convergence Index: it is the only instrument that currently harnesses the power of formal and substantive consumer contract law data that can showcase it in a comprehensive yet flexible manner. To the extent that it is based on coding the law in the light of specific assumptions, such approaches to comparative analysis can lead to the creation of Big Law data: the volume of legal knowledge can be tapped into for more systemic research purposes.

\section{Why Treat Law as Big Data? On Alternative Comparative Methods}

Technology has undeniably had an impact on legal research and legal research methodologies, and this idea has been highlighted by scholars in one shape or another for years now (Smith 2007, pp. 309-354; Katz \& Bommarito II 2014, pp. 337-374). Benchmarking/indexing exercises are one example of how law can be turned into data and further researched in a way that can complement more 
classical legal inquiries. Other methods can be equally useful in this respect. ${ }^{22}$ However, there is one essential requirement for all related endeavours: gathering the necessary data. Any researcher trying to study legal developments by gathering all sorts of relevant statistics soon discovers that they are very difficult to come about, because of two separate factors: on the one hand, statistics that are relevant from a legally substantive perspective are scarce; on the other hand, own researcher databases and statistics are rare and difficult to verify.

On a similar note, a long-standing debate regarding the legal discipline has to do with whether law is considered a science or not (Faignman 1989, p. 1007; Coyle \& Pavlakos 2005); Langford et al. 2017; Mertz 2008. This debate may echo the point that the scientific method as an iterative process (formulating hypotheses, developing testable predictions, testing predictions, developing general theories) is not suitable for law, which in turn has developed its own sui generis methods. Similarly, this view may also touch upon the fact that the vast majority of legal research is generally not reproducible. After all, doctrinal legal research consists of interpretative opinions generated through legal argumentation and reasoning. Empirical methods open themselves to the notion of reproducibility, although the practice of actually taking the step to reproduce a legal empirical study is obscure at best. This article does not aim to shed light on any classification arguments the legal discipline has been in the centre of, but to shift the focus to a different question. Reproducibility entails the publication of data, so that other researchers can check results or, even beyond that, build on existing knowledge by employing the data in different ways. Why should law not establish methods or tools that can have this effect, and that can be used interchangeably in different fields or for different issues, to also contribute to the body of existing legal knowledge in a different manner than it currently does?

To answer this question, I will use two different perspectives. First, from a normative point of view, as seen in the earlier section, treating law as data can open the door to a new, facilitated visualization and understanding of different legal issues. Legal information already fits the three main characteristics of Big Data: the 3 Vs - volume, variety and velocity (Joubert 2015, p. 6), and additional sources that can facilitate the gathering of such information are by no means few. An example in this respect is the data produced by citizens on social media platforms such as Twitter. With 302 million active users in 2015, and a reported 500 million tweets per day in November 2015 (Oreskovic 2015), Twitter is an archive of opinions and displays of human behaviour around the world. Other disciplines such as psychology (Eichstaedt et al. 2015, pp. 159-169) or anthropology (AumanBauer 2017) are already channelling the potential of this data, and special tools have already been developed to this end (see, for instance, Burnap et al. 2015, pp. 80-100; Hussain \& Vatrapu 2014, pp. 368-372). ${ }^{23}$ One can only imagine the

Another example of a method that can use legal Big Data is case network analysis; see Netherlands eScience Center 2017.

23 See also the open-source software Lentil, developed at North Carolina State University, available at https://www.lib.ncsu.edu/social-media-archives-toolkit/collecting/lentil-user-guide, last visited on 24 July 2017. 
possibilities of analysing such media from a legal perspective, ranging from whether Twitter users actually perceive the legal implications of their comments (Piper 2017), to investigating consumer behaviour or measuring the compliance of social media influencers with rules requiring them to disclose information regarding endorsements (Goanta 2017).

Second, from an accessibility point of view, the technical solutions that can be employed in legal research already exist and can be easily adapted to the specific needs of researchers. A telling example is network analysis, a method notably used in computer science and sociology, that 'maps and measures relationships, between, for example, people, groups, computers, or information' (Fowler 2007, p. 325; see also Lupu \& Voeten 2012, pp. 413-439). While the traditional way of analysing case law has been to synthesize the number of consulted court decisions for a given legal issue, case network analysis opens the possibility for a researcher - or for that matter anyone interested in case law - to be able to visualize an entire field with the help of technical aid. ${ }^{24}$

At the same time, law firms trying to stay ahead of the pack are already employing Big Data tools. ${ }^{25}$ This leaves the research world behind to more traditional uses of technology, such as retrieving scholarly articles from centralized databases such as LexisNexis, Westlaw or HeinOnline, while legal practice transitions to the use of technologies such as optical character recognition to deploy artificial intelligence in finding information patterns (Marr 2016). ${ }^{26}$ In addition, services such as Vraaghugo.nl, selling modular contracts to small-scale businesses, operate entirely online, and the transactions themselves become data. Aggregated, research that involves such market players can help academics and regulators gain a realistic view of the immediate reality they are engaged with: what are the most purchased contracts by small business operators; what are the most problematic areas for such actors? Acknowledging questions like these in legal research can lead to meaningful contributions with direct societal impact. Joint initiatives operated by technology companies in collaboration with academic institutions are already giving rise to research that is relevant both from an industry and from a scholarly perspective. ${ }^{27}$ Indeed, it might be necessary to draw a line between legal information that can be subjected to coding and legal information that, by its very nature, requires much more interpretation, but this point in itself does not deny the need to complement existing doctrinal research with methods that allow for a more widespread systematic study of legal information.

25 See, for instance, Juristat, a tool predicting the success of patent prosecution (www.juristat. com) or Ravel's Judges Analytics (https://www.ravellaw.com/judges), allowing users to map every decision made by a selected judge.

26 See also Lawbot, an example of an artificial intelligence tool applied to analysing licence agreements: http://www.lawbot.co. Another example is ROSS Intelligence (http://www.rossintelligence.com), an artificial intelligence tool that analyzes information to find data patterns and make connections otherwise invisible.

27 See, for instance, the Facebook Academics initiative, available at https://research.fb.com, last visited on 24 July 2017. An example of research conducted within the ambit of this initiative is Lewis et al. 2017. 
To summarize the points I have been making so far in this Section, not only is there potential for considerable developments in legal research by looking at legally relevant information as data, but the infrastructure to do so is already there, and some scholars have been embracing this approach. So why is it that comparative law was not already revolutionized by such views?

On the one hand, for comparative law, the notion of treating legal information (e.g. case law, legal provisions, literature) as Big Data could be transformative. Comparative law, as a legal method that is trying to prove its usefulness in the 21st century, has been so far based on small-scale comparisons, and the higher the number of chosen jurisdictions, the bigger the research effort in terms of persons, time and other resources. This is evidenced by the massive resources going into transposition studies such as the Consumer Law Compendium.

On the other hand, as the status of comparative law has been heavily debated (Reimann 1996, p. 49; Siems 2007, pp. 133-150; Michaels 2016, pp. 352-358; Siems 2016, pp. 359-365; Mattei 2002, p. 87), its challenges propagated onto the greater debate surrounding the methods used in the academic study of law as a projection of its nature. In day-to-day academic affairs, legal scholars remain divided on what legal research is and what it is not. Still, even though there are benefits in both defending and questioning the status quo of the study of law, one consideration prevails: the purpose of legal research is to understand the legally relevant complexities of society; and as long as this purpose is attained by allowing legal inquiry to match technological developments (e.g. looking at the law as data), it does not matter whether the inquiry as such is categorized as falling under the legal discipline or under data science, but what matters is that it can bring a significant academic contribution. After all, re-envisaging the usefulness of legal information need not replace traditional legal methods but rather complement them. While more traditional academia is not convinced by coding the law, ${ }^{28}$ this activity remains greatly promising.

\section{Conclusion}

This contribution is about the need to look at legal information as Big Data. As the Introduction explores, society is changing, and law and its analysis need to keep moving with it. This leads to volumes of data on a plethora of legal fields and issues being generated at an increasingly fast pace. While classical legal methods maintain their value in the development of the legal discipline, certain questions cannot be answered in these traditional ways.

In Section 2, this article visits the particularities of European consumer contract law and briefly explains the types of ways in which the Convergence Index can be used. An example of the use of law as data is the Convergence Index further 
explored in Section 3, initially designed for European consumer contract law but that can be applied throughout any field of European law which is currently missing a benchmarking tool. The aims of the Convergence Index are to (i) trigger a discussion about what harmonization policies have achieved since their introduction; (ii) explore factors relevant for legal convergence and their performance; (iii) offer a comparison between different types of directives (minimum v. maximum harmonization); and (iv) allow further research to build on legal convergence by potentially testing the hypothesis that more harmonization leads to a healthier internal market. Section 4 generally discusses why legal information can and should qualify as Big Data, and briefly touches upon some potential applications. All in all, comparative law in the 21st century might just as well be defined by technology, in an attempt to provide more speed, more tailoring or more accessibility to the academic purpose of comparing laws.

\section{References}

Auman-Bauer, K. (2017). Twitter data changing future of population research. Penn State News. http://news.psu.edu/story/474782/2017/07/17/research/twitter-datachanging-future-population-research. Last visited on 24 July 2017.

Bar-Gill, O. \& Ben-Shahar, O. (2013). Regulatory techniques in consumer protection: a critique of European consumer contract law. Common Market Law Review, 50: 109-125.

Blichner, L.C. \& Molander, A. (2005). What is juridification? Oslo Center of European Studies Working Paper 14/2005.

Blichner, L.C. \& Molander, A. (2008). Mapping juridification. European Law Journal, 14(1): 36-54.

Bull, W., Bull, W., Ge, J., Goanta, C., Kawakami, M. \& Smits, J.M. (2015). Who does what in consumer law? A search for criteria for centralised lawmaking. In B. Akkermans, J. Hage, N. Kornet, \& J. Smits (Eds.), Who does what?: On the allocation of regulatory competences in European private law (pp. 97-123). Intersentia.

Burnap, P., Rana, O., Williams, M., Housley, W., Edwards, A., Morgan, J., Sloan, L. \& Conejero, J. (2015). COSMOS: towards an integrated and scalable service for analysing social media on demand. International Journal of Parallel, Emergent and Distributed Systems, 30(2): 80-100.

Cafaggi, F. (2008). The making of European private law: governance design. In F. Cafaggi \& H. Muir-Watt (Eds.), Making European private law: governance design (pp. 289-352). Cheltenham: Edward Elgar Publishing.

Chen, M., Mao, S. \& Liu, Y. et al. (2014). Big data: a survey. Mobile Networks and Applications, 19(2): 171-209.

Chevalier, D. (2016). The production of law: law in action in the everyday and the juridical consequences of juridification. Recht der Werkelijkheid, 3: 116-133.

Coyle, S. \& Pavlakos, G. (Eds.), Jurisprudence or legal science? A debate about the nature of legal theory. Oxford: Hart Publishing.

Djankov, S., La Porta, R., Lopez-de-Silanes, F. \& Shleifer, A. (2002). Courts: the lex mundi project. National Bureau of Economic Research Working Paper 8890.

Eichstaedt, J.C., Schwartz, H.A., Kern, M., Park, G., Labarthe, D.R., Merchang, R.M., Jha, S., Agrawal, M., Dziurzynski, L.A., Sap, M., Weeg, C., Larson, E.E., Ungar, L.H. \& Seligman, M.E.P. (2015). Psychological language on Twitter predicts county-level heart disease mortality. Psychology Science, 26(2): 159-169. 
Epstein, R. (2012). Harmonisation, heterogeneity and regulation: why the common European sales law should be scrapped. www.law.uchicago.edu/files/files/RAE\%20paper. pdf, p. 6.

Faignman, D.L. (1989). To have and have not: assessing the value of social science to the law as science and policy. Emory Law Journal, 38: 1005-1095.

Fowler, J.H. (2007). Network analysis and the law: measuring the legal importance of precedents at the U.S. Supreme Court. Political Analysis, 15: 324-346.

Goanta, C. (2016). Convergence in European consumer sales law, a comparative and numerical approach. Antwerp: Intersentia.

Goanta, C. (2017). Consumers on fyre: influencer marketing and recent reactions of the United States Federal Trade Commission. Stanford Transatlantic Technology Law Forum Newsletter 3. https://law.stanford.edu/transatlantic-technology-law-forum/news letter/. Last visited on 24 July 2017.

Gómez, F. \& Gili-Saldaña, M. (2014). Termination as a remedy in the common European sales law: a law and economics approach. European Review of Contract Law, 10(3): 331364.

Gómez-Pomar, F. \& Ganuza, J.J. (2011). Economic underpinnings of European private law harmonisation. In R. Schulze \& H. Schulte-Nölke (Eds.), European private law - current status and perspectives (pp. 27-56). München: Sellier.

Goode, F. (2003). Contract and commercial law: The logic and limits of harmonisation. Electronic Journal of Comparative Law, 7(4). http://www.ejcl.org/74/art74-1.html.

Hondius, H. (2017). Kroniek algemeen. NTBR 2017/9.

Hussain, A. \& Vatrapu, R. (2014). Social Data Analytics Tool (SODATO). In M.C. Tremblay, VanderMeer, D., Rothenberger, M., Gupta, A., \& Heidelberg, V.Y. (Eds.), Advancing the impact of design science: moving from theory to practice (pp. 368-372). DESRIST. Lecture Notes in Computer Science. Cham: Springer.

Joubert, G.R. (2015). Big data: insights and the scientific method. In L. Grandinetti, Joubert, G., Kunze, M. \& Pascucci, V. (Eds.), Big data and high performance computing (pp. 3-17). Amsterdam: IOS Press.

Katz, D.M. \& Bommarito II, M.J. (2014). Measuring the complexity of the law: The United States Code. Artificial Intelligence and Law, 22(4): 337-374.

Langford, P., Bryan, I. \& McGarry, J. (Eds.), (2017). Kelsenian legal science and the nature of law. Cham: Springer.

Levi-Faur, D. (2005). The political economy of legal globalization: juridification, adversarial legalism, and responsive regulation. A comment. International Organization, 59(2): 451-462.

Lewis, M., Yarats, D., Dauphin, Y.N., Parikh, D. \& Batra, D. (2017). Deal or no deal? End-toend learning for negotiation dialogues. https://arxiv.org/pdf/1706.05125.pdf. Last visited on 24 July 2017.

Lookofsky, J. (2000). The harmonization of private and commercial law: 'towards a European civil code'. International Aspects: 111-122.

Loos, M. (2007). The influence of European consumer law on general contract law and the need for spontaneous harmonization - on the disturbance and reconstruction of the coherence of national contract law and consumer law under the influence of European law. European Review of Private Law, 15(4): 515-531.

Lupu, Y. \& Voeten, E. (2012). Precedent in international courts: a network analysis of case citations by the European Court of Human Rights. British Journal of Political Science, 42(2): 413-439.

Magnussen, A.-M. \& Banasiak, A. (2013). Juridification: disrupting the relationship between law and politics? European Law Journal, 19(3): 325-339. 
Marotta-Wurgler, F. (2007). What's in a standard form contract? An empirical analysis of software license agreements. Journal of Empirical Legal Studies, 4(4): 677-713.

Marr, B. (2016). How big data is disrupting law firms and the legal profession. https:// www.forbes.com/sites/bernardmarr/2016/01/20/how-big-data-is-disrupting-lawfirms-and-the-legal-profession/2/\#140672535157.

Mattei, U. (2002). Some realisms about comparativism: comparative law. The American Journal of Comparative Law, 50(1): 87-99.

Mertz, E. (2008). The role of social science in law. Farnham: Ashgate.

Michaels, R. (2016). Transnationalising comparative law. Maastricht Journal of European and Comparative Law, 23(2): 352-358.

Micklitz, H.-W. \& Reich, N. (2014). The court and Sleeping Beauty: the revival of the unfair contract terms directive. Common Market Law Review, 51: 771-808.

Micklitz, H.-W. (2002). An expanded and systematized community consumer law as alternative or complement? European Business Law Review, 13(6): 583-598.

Netherlands eScience Center (2017). How can network analysis lead to a new way of studying court decisions?. https://medium.com/escience-center/how-can-networkanalysis-lead-to-a-new-way-of-studying-court-decisions-686ccf4d46aa.

OECD (2008). Handbook on constructing composite indicators: methodology and user guide. http://www.oecd.org/std/42495745.pdf.

Oreskovic, A. (2015). Here's another area where Twitter appears to have stalled: tweets per day. Business Insider. http://www.businessinsider.com/twitter-tweets-per-dayappears-to-have-stalled-2015-6?international=true\&r=US\&IR=T. Last visited on 24 July 2017.

Piper, D.L.A. (2011). Social media - new laws for new attitudes. http://files.dlapiper.com/ files/Uploads/Documents/Shifting_Landscapes_Report_5_Social_Media.pdf. Last visited on 24 July 2017.

Reimann, M. (1996). The end of comparative law as an autonomous subject. Tulane European and Civil Law Forum, 11: 49-72.

Schulte-Nölke, H., Twigg-Flesner, C. \& Ebers, M. (2009). EC Consumer Law Compendium: The Consumer Acquis and its transposition in the Member States. De Gruyter.

Siems, M. (2005). Numerical comparative law: do we need statistical evidence in law in order to reduce complexity. Cardozo Journal of International and Comparative Law, 13:521-540.

Siems, M. (2007). The end of comparative law. Journal of Comparative Law, 2: 133-150.

Siems, M. (2014). Comparative law. Cambridge: Cambridge University Press.

Siems, M. (2016). Comparative law in the $22^{\text {nd }}$ century. Maastricht Journal of European and Comparative Law, 23(2): 359-365.

Smith, T. (2007). The web of law. San Diego Law Review, 44: 309-354.

Smits, J. (2017). What is legal doctrine? On the aims and methods of doctrinal legal research. In: R. Van Gestel, H.-W. Micklitz \& E.L. Rubin, (Eds.), Rethinking legal scholarship (pp. 207-228). Cambridge: Cambridge University Press.

Sørensen, M.J. (2016). In the name of effective consumer protection and public policy! European Review of Private Law, 24(5): 791-822.

Staudenmayer, D. (2005). The way forward in European contract law. European Review of Private Law, 13(2): 95-104.

Teubner, G. (1987). Juridification of social spheres: a comparative analysis in the areas of labor, corporate, antitrust and social welfare law. De Gruyter.

Teubner, G. (1998). Juridification: concepts, aspects, limits, solutions. In R. Baldwin, C. Scott, \& C. Hood (Eds.), A reader on regulation (pp. 389-440). Oxford: Oxford University Press. 
Twigg-Flesner, C. (2012). The (non-)impact of harmonizing measures on English legal terminology. European Review of Private Law, 20(5-6): 1369-1378.

van Hoecke, M. (2015). Methodology of comparative legal research. Law and Method, December issue.

van Leeuwen, B. J. (2017). European standardisation of services and its impact on private law: paradoxes of convergence. Bloomsbury Publishing, p. 36.

van Zelst, B. (2008). The politics of European sales law: a legal-political inquiry into the drafting of the uniform commercial code, the Vienna Sales Convention, the Dutch Civil Code and the European Consumer Sales Directive in the context of the Europeanization of contract law. The Hague: Kluwer Law International.

Vranken, J. (2012). Exciting times for legal scholarship. Law and Method, https:// www.bjutijdschriften.nl/tijdschrift/lawandmethod/2012/2/ReM_2212-2508_ 2012_002_002_004. 